\title{
Knowledge, Attitudes and Behaviours Concerning Sustainable Development: A Study among Prospective Elementary Teachers
}

\author{
Francisco Borges ${ }^{1}$ \\ ${ }^{1}$ Institute of Education, University of Minho, Braga, Portugal \\ Correspondence: Francisco Borges, Institute of Education, Campus of Gualtar, 4710-057 Braga, Portugal. E-mail: \\ borges@ie.uminho.pt
}

Received: January 4, 2019

Accepted: January 25, 2019 Online Published: February 23, 2019

doi:10.5539/hes.v9n2p22

URL: https://doi.org/10.5539/hes.v9n2p22

\begin{abstract}
The aim of this study consisted in assessing knowledge, attitudes and behaviours concerning various aspects of sustainable development in a group of Portuguese university students and measure the influence of area of study for admission to higher education on this dimensions. The collection of data was undertaken via the completion of a questionnaire, which was designed to include the following dimensions: knowledge, attitudes and behaviours. This initiative took place in the 2016/2017 academic year and the focus/target group for was constituted by 168 prospective elementary teachers. The validation procedures of the questionnaire confirmed its three-dimensional structure. The results obtained showed the existence of very favourable knowledge and attitudes regarding sustainable development. Behaviours proved less favourable than the other two dimensions. In addition, the results show that respondents' area of study for admission to higher education has no influence regarding knowledge, attitudes and behaviours concerning sustainable development. Finally some implications for teachers and students are raised and discussed.
\end{abstract}

Keywords: sustainable development, knowledge, attitudes, behaviours, higher education

\section{Introduction}

Firmly rooted in environmental education (EE), the concept of sustainable development (SD), popularized in 1987 by the Brundtland Commission Report, arose in response to questions raised about the need to redefine the notion of "development" with regard to persistent degradation of environmental quality ten years after Tiblisi, 1977 (Scoulos \& Malotidi, 2004).

The challenges posed by incorporation of the concept of sustainable development (SD) in EE were discussed at the 1992 United Nations Conference on Environment and Development, held in Rio de Janeiro, leading to the establishment of Agenda 21 (UNCED, 1993) which aimed at reorienting the EE towards sustainability (Tilbury, 1995). This program was a milestone in support for introducing SD into curricula at all levels of education. However, the practical results of Agenda 21 in the field of education did not live up to the expectations generated and in 2002 the World Conference on Sustainable Development, held in Johannesburg, reaffirmed the need for integration of SD at all levels of the education system and recommended the United Nations Educational, Scientific and Cultural Organization (UNESCO) to adopt the Decade of Education for Sustainable Development (Scoulos \& Malotidi, 2004).

If, on the one hand, the Decade of Education for Sustainable Development (UNESCO, 2003) resulted internationally in a shift from discourse on environmental education to education for sustainable development (ESD); on the other hand, the question remains whether the change in discourse and language was accompanied by a real change in educational practice (Robottom, 2013). Reflecting on educational policies in EE/ESD, Stevenson (2013) draws attention to the separation that exists between the formulation of educational policies, which often emanate from supranational organizations, implicitly adopting the top-down model, and their actual implementation in educational practice.

Robottom (2013) considers how best to respond to a situation wherein educators find themselves facing a contextual shift from the discourse of EE to that of ESD, yet with no clear definition of the practical changes arising from this transition. He questions how educators may "develop a greater understanding of the complexity of their own professional circumstances" (p.158). The way in which teachers and students conceptualize SD can 
have consequences for the way that they incorporate it into their teaching and learning, respectively (Borg, Gericke, Höglund \& Bergman, 2012; Singer-Brodowski, 2017).

In the particular case of higher education, Singer-Brodowski (2017) claims that, unlike in other fields, little research has been conducted on students' conceptions about SD and the same needs towards teachers was expressed by Cotton, Warren, Maiboroda, and Bailey (2007), who claimed that little research exists on lecturers' understanding of and attitudes towards SD. As far as Portugal is concerned, the research in the field of SD/ESD has experienced a considerable growth, in particular under the influence of the UNESCO Decade of Education for Sustainable Development 2005-2014 (Borges \& Benayas, 2019) We can highlight, for example, recent studies about new educational strategies (Azeiteiro, Nicolau, Caetano \& Caeiro, 2015) and about the implementation of SD/EDS in higher education (Torres, Vieira, Rodrigues, Sá, \& Moreira, 2017; Aleixo, Azeiteiro \& Leal, 2018). However, little research has been conduced on students or lecturers' understandings, attitudes or behaviours concerning SD. The present study aims to produce knowledge on this regard.

On this regard, we can mention some studies that focus on factors associated with teaching, such as: Borg et al. (2012; 2014), who have examined the influence of teachers' subject area and their pedagogical experience in the ESD approach according to the holistic model; Burmeister and Eilks (2013) who attempt to highlight the understanding of sustainability and education for sustainable development among German student teachers and trainee teachers of chemistry; Ull, Piñero, Martínez-Agut and Minguet (2014), who have analysed the perceptions and attitudes of primary teachers with regard to the incorporation of sustainability in their subjects; Ambusaidi and Washahi (2016), who have studied how prospective teachers in Oman perceive the concept of SD and Keles (2017) investigated the pre-service science teachers' attitudes towards sustainable environmental education in terms of gender and grade level.

Other studies have focused their research on factors more directly related to students, including measuring knowledge, attitudes and behaviours concerning ESD/SD among both adults and primary and secondary school students (Michalos, Creech, McDonald \& Kahlke, 2011) and 10 $0^{\text {th }}$ grade students (Michalos et al., 2012); evaluating attitudes regarding SD in Italian university students (Biasutti \& Frate, 2017); assessing the attitudes and behaviours of university students in Cyprus (Gündüz, 2017); evaluating the effect of ESD teaching on the environmental awareness of Swedish elementary school students (Olsson, Gerickea \& Chang Rundgrenb, 2016); and investigate United Arab Emirates University students' knowledge, attitudes and behaviors toward education for sustainable development and the environment (Al-Naqbi \& Alshannag, 2018).

The present study seeks to evaluate knowledge, attitudes and behaviours concerning SD among a group of Portuguese university students, prospective teachers in elementary education. More specifically, it aims to evaluate knowledge regarding the relevance of SD-specific themes; behaviours with respect to SD themes, understood as "the self-reported intentions to act associated with those themes"; and attitudes toward SD themes defined here according to Eagly and Chaiken (2005) as: "a psychological tendency that is expressed by evaluating a particular entity with some degree of favor or disfavor" (p.745). In addition, it investigates whether the students' education profile prior to entering the university has any influence regarding the above dimensions. After reviewing the literature for research instruments that could help fulfil this purpose, a questionnaire was selected used by Michalos et al. (2011) in their exploratory study with adults in the Canadian province of Manitoba.

This instrument was used to measure levels of knowledge, attitudes and behaviours concerning ESD/ SD and the themes that it included were chosen based on the strategic outlook outlined by UNESCO (2006), namely: human rights, peace and human security, gender equality, cultural diversity and intercultural understanding, health, HIV/AIDS, governance, natural resources, climate change, rural development, sustainable urbanisation, disaster prevention and mitigation, poverty reduction, corporate responsibility and accountability, and the market economy (Michalos et al., 2011).

\subsection{Research Aims}

a) to assess knowledge, attitudes and behaviours concerning various aspects of sustainable development among a group of prospective elementary educators.

b) to measure the influence of the area of study for admission to higher education, on knowledge, attitudes and behaviours concerning sustainable development.

\section{Method}

\subsection{The Subjects}

A group of 168 students from a public Portuguese university participated in this study. This number amounts to 
$73.3 \%$ of the total of 229 students attending the following degrees in the 2016/2017 academic year: Bachelor's Degree in Elementary Education, Master's Degree in Pre-school and 1st Cycle of Elementary Education, Master's in Pre-school Education. The respondents' ages ranged from 18 to 33, and the majority (78.6\%) were under 23 . The group was predominantly comprised of females $(95.8 \%)$ with only seven respondents being male $(4.2 \%)$.

The degrees/year attended by the 168 students participating in the study are distributed as follows - Bachelor's degree: $27.4 \%$ from the $1^{\text {st }}$ year, $19 \%$ from the $2^{\text {nd }}$ year, and $21.4 \%$ from the $3^{\text {rd }}$ year; Master's degree in Preschool Education and Elementary School Teaching: $12.5 \%$ from the $1^{\text {st }}$ year, $11.3 \%$ from the $2^{\text {nd }}$ year; Master's in Preschool Education: $8.3 \%$ from the $1^{\text {st }}$ year.

As regards area of study for admission to higher education, $45.7 \%$ of respondents surveyed came from the fields of science and technology, $37.2 \%$ from languages and humanities, $8.5 \%$ from the vocational education sector, $4.3 \%$ from the arts, and another $4.3 \%$ from the field of socioeconomic sciences.

\subsection{The Questionnaire}

The translated version of the original questionnaire by Michalos et al. (2011), which included assessment of the dimensions of knowledge, attitudes and behaviours, was given to a small group of subjects with similar characteristics to the individuals in the main study. This preliminary study resulted in several changes affecting the items included in the knowledge and behaviours dimensions, namely, the exclusion of some items and the addition of others. The "attitudes" dimension remained unaltered vis-à-vis the initial version.

These changes were mainly intended to adjust the content of items to the specific group of subjects surveyed in the present study and they were carried out taking the original number of items and their relevance to the UNESCO perspective on SD into account. The following are examples of excluded items: "Canada's overall energy is improving", from the knowledge dimension; "I do not use chemical fertilisers or pesticides on my lawn", from the behaviours dimension. In turn, the following are examples of new items: "economic development emphasises international cooperation", from the knowledge dimension; "I have already participated in activities related to sustainable development", from the behaviours dimension.

Content validity of the items resulting from this preliminary study was accomplished through the opinion of a panel of experts composed of three professors who commented on the ambiguity of the items, on their appropriacy to the subject group in question and on the respective formulation.

The answer format chosen for the items in the knowledge and attitudes dimensions was a five-point Likert scale, ranging from Strongly Disagree (sd, coded 1), corresponding to the least favourable answer, through Disagree (d, coded 2), Neither agree nor disagree (nand, coded 3), and Agree (a, coded 4) to Strongly Agree (sa, coded 5), corresponding to the most favourable answer.

Regarding the behaviours dimension, a 5-point frequency scale was used, which ranged between the following points: Never (n, coded 1), corresponding to the least favourable answer, Rarely (r, coded 2), Regularly (re, coded 3), Often (o, coded 4) and Very Often (vo, coded 5), corresponding to the most favourable answer.

As for the items which refuted the construct, the scores were reversed. The items were numbered and arranged on the questionnaire according to their respective dimensions. The following notation was used: knowledge - $\mathrm{K}$ followed by item number, attitudes - A followed by item number, and behaviours - B followed by item number.

The questionnaires were handed out in person by the researcher in the 2016/2017 academic year, and the subjects participated on a voluntary and anonymous basis.

The questionnaire that resulted from the procedures described hitherto was composed of 41 items distributed by dimension, as follows: knowledge (14); attitudes (15) and behaviours (12).

\subsection{Questionnaire Dimensionality}

Given the specificities of the participating subjects, as well as the differences resulting from the amendments made to the original instrument, we decided to proceed with an assessment of the instrument's factor structure and the internal consistency of the items in each dimension. Assessment of the dimensional structure of the questionnaire was conducted through factor analysis (Table 1) as recommended by DeVellis (2012). 
Table 1. Rotated factor matrix

\begin{tabular}{|c|c|c|c|}
\hline Items & Factor 1 & Factor 2 & Factor 3 \\
\hline K4 Ensuring a long and healthy life for all contributes to sustainable development. & .758 & & \\
\hline K6 Sustainable development requires quality education for all. & .727 & & \\
\hline K3 Sustainable development emphasises respect for human rights. & .571 & & \\
\hline A6 Poverty alleviation is an important topic in education for sustainable development. & .568 & & .256 \\
\hline K8 Sustainable development entails a reflection on the meaning of quality of life. & .509 & & .362 \\
\hline $\begin{array}{l}\text { K1 Helping people out of poverty is an essential condition for Portugal to become more } \\
\text { sustainable. }\end{array}$ & .491 & & \\
\hline K5 Building appropriate infrastructures contributes to sustainable development. & .472 & & .207 \\
\hline K7 Sustainable development emphasises gender equality. & .421 & & \\
\hline $\mathrm{K} 12$ Food safety is one aim of sustainable development. & .373 & & \\
\hline $\begin{array}{l}\text { K13 Estimating the monetary value of the service our ecosystems provide (such as: neutralising } \\
\text { air pollutants) is important for sustainable development. }\end{array}$ & .361 & & .307 \\
\hline K14 Sustainable development emphasises international cooperation. & .381 & & .382 \\
\hline B2 I have taken a course in which sustainable development was discussed. & & .704 & \\
\hline B8 I have already participated in activities related to environmental sustainability. & & .701 & \\
\hline B4 I have been thinking about what it means to live in a sustainable manner. & & .679 & .207 \\
\hline $\begin{array}{l}\text { B12 I have already looked up information about the new sustainable development goals of the } \\
\text { United Nations. }\end{array}$ & & .643 & \\
\hline B6 I often look for signs of ecosystem deterioration. & & .618 & \\
\hline B3 I talk to others about how to help people living in poverty. & & .614 & \\
\hline $\begin{array}{l}\text { B11 I have already looked up information about the environment or sustainability of the } \\
\text { university on the respective website. }\end{array}$ & & .604 & \\
\hline B10 I usually look at problems from different angles. & & .435 & \\
\hline B1 I walk or bike to places instead of going by car. & & .390 & \\
\hline B7 I volunteer to work with local charities. & & .387 & \\
\hline $\begin{array}{l}\text { B9 I try to avoid purchasing goods from companies with poor track records on corporate social } \\
\text { responsibility. }\end{array}$ & & .368 & \\
\hline $\begin{array}{l}\text { B5 The household tasks in my home are equally shared among family members regardless of } \\
\text { gender. }\end{array}$ & & .311 & \\
\hline A5 We need stricter laws and regulations to protect the environment. & .220 & & 696 \\
\hline A10 Governments should encourage greater use of fuel-efficient vehicles. & & & .629 \\
\hline $\begin{array}{l}\text { A11 Adopting sustainable development as a national priority is key to maintaining Portugal's status } \\
\text { as one of the most liveable countries in the world. }\end{array}$ & .386 & & .613 \\
\hline $\begin{array}{l}\text { A9 The teaching of sustainability principles should be integrated into the curriculum in all } \\
\text { disciplines and at all levels of schooling. }\end{array}$ & .259 & & .591 \\
\hline A12 Citizenship education is an important component of education for sustainable development. & .307 & & .548 \\
\hline $\begin{array}{l}\text { A1 Every girl or boy should receive education that teaches the knowledge, perspectives, values, } \\
\text { issues and skills for sustainable living in a community. }\end{array}$ & .370 & & .487 \\
\hline $\begin{array}{l}\text { A4 Overuse of our natural resources is a serious threat for the health and welfare of future } \\
\text { generations. }\end{array}$ & & & .459 \\
\hline $\begin{array}{l}\text { A } 2 \text { The present generation should ensure that the next generation inherits a community at least as } \\
\text { healthy, diverse and productive as it is today. }\end{array}$ & .355 & & .442 \\
\hline $\begin{array}{l}\text { A7 Sustainable development will not be possible until wealthier nations stop exploiting the labour } \\
\text { and natural resources of poorer countries. }\end{array}$ & & & .418 \\
\hline A3 Manufacturers should discourage the use of disposables. & & & .364 \\
\hline $\begin{array}{l}\text { A13 Taxes on polluters should be increased to pay for damage to communities and the } \\
\text { environment. }\end{array}$ & .212 & & .325 \\
\hline Eigenvalue & 7.08 & 3.99 & 2.19 \\
\hline$\%$ of total variation & 19.03 & 9.75 & 5.35 \\
\hline
\end{tabular}

It was crucial to obtain information on the dimensional structure of the instrument in order to guarantee the possibility of working with collections of combined items within a composite (dimension).

All items which displayed loaded values greater than 0.30 have been highlighted in bold and kept for further 
analysis. Whenever an item was loaded on more than one factor, the highest value was considered, such as, for example, in the case of item A6.

As can be seen in Table 1, the questionnaire maintained its three-dimensional structure. The factors account for $34.1 \%$ of total variance and they are distributed as follows: factor 1 (knowledge), factor 2 (behaviours), and factor 3 (attitudes).

The items associated with each factor were subjected to an internal consistency and reliability assessment, based on Cronbach's alpha coefficient (Table 2).

Table 2. Cronbach's alpha reliability coefficient for each factor, scale mean and standard deviation

\begin{tabular}{|c|c|c|c|c|c|}
\hline \multicolumn{2}{|c|}{$\begin{array}{l}\text { Factor1 (knowledge) } \\
\alpha \text { Cronbach } 0.84(\mathrm{~N}=167) \\
\text { Scale mean: } 45,4^{*}( \pm 5.0)\end{array}$} & \multicolumn{2}{|c|}{$\begin{array}{l}\text { Factor } 2 \text { (behaviours) } \\
\alpha \text { Cronbach } 0.83(\mathrm{~N}=160) \\
\text { Scale mean: } 35.1^{* *}( \pm 7.9)\end{array}$} & \multicolumn{2}{|c|}{$\begin{array}{l}\text { Factor } 3 \text { (attitudes) } \\
\alpha \text { Cronbach } 0.82(\mathrm{~N}=167) \\
\text { Scale mean: } 43.7 * * *( \pm 4.2)\end{array}$} \\
\hline Items & $\begin{array}{l}\text { Item-total } \\
\text { correlation }\end{array}$ & Items & $\begin{array}{l}\text { Item-total } \\
\text { correlation }\end{array}$ & Items & $\begin{array}{l}\text { Item-total } \\
\text { correlation }\end{array}$ \\
\hline K4 & .68 & B8 & .66 & A5 & .70 \\
\hline K6 & .62 & B4 & .63 & A11 & .67 \\
\hline K8 & .59 & B2 & .62 & A10 & .62 \\
\hline K3 & .57 & B12 & .59 & A9 & .59 \\
\hline $\mathrm{A} 6^{\mathrm{a}}$ & .56 & B11 & .55 & A12 & .58 \\
\hline K14 & .48 & B6 & .54 & A1 & .56 \\
\hline K5 & .47 & B3 & .54 & A2 & .48 \\
\hline K1 & .46 & B10 & .41 & A7 & .43 \\
\hline K12 & .44 & B1 & .39 & A13 & .37 \\
\hline K13 & .44 & B9 & .38 & A4 & .30 \\
\hline \multirow[t]{2}{*}{ K7 } & .42 & B7 & .33 & $A 3^{b}$ & \\
\hline & & B5 & .31 & & \\
\hline
\end{tabular}

Note. ${ }^{*} \max .55 ;{ }^{* *} \max .60 ;{ }^{* * *} \max .50 ;{ }^{\mathbf{a}}$ item added to the scale; ${ }^{\mathbf{b}}$ item eliminated from the scale.

As shown in the table above, all the dimensions have high $\alpha$ coefficients. High alpha $(\alpha)$ values, i.e. equal to or higher than .80, indicate that the items are strongly correlated (DeVellis, 2012).

Analysis of the correlation coefficients obtained for each item shows that they take on values equal to or higher than .30 .

With respect to the scales of both attitudes and behaviours, we tested the effect of eliminating the items with the lowest correlation coefficients (below .40). We observed that when these items were retained, coefficient $\alpha$ either remained unaltered or increased, except for item A3, which, if retained, caused the coefficient value to decrease, and for that reason it was discarded. Regarding item A6, calculation of the $\alpha$ value confirmed that by including it in the knowledge scale, the value of the respective coefficient increased, for which reason it was included in the knowledge dimension, with the designation K15.

As a result of the validation procedures described above, 33 items were selected for further analysis. The elimination of some items during the validation processes led, on the one hand, to the loss of the information associated with those items, thus causing a limitation to this study. However, it afforded greater confidence in the consistency of the instrument.

For statistical procedures, we chose to keep the designations of the items in the order in which they appeared in the questionnaire.

\subsection{Data Analysis}

Analysis of the data pertaining to the sociodemographic characterisation of the subjects who participated in the study was based on the calculation of frequency and percentage values.

As regards the data from the remainder of the questionnaire, the following procedures were used: calculation of frequency and percentage values of the answers given to each item and mean and standard deviation for each dimension. Furthermore, correlations among dimensions were calculated through Pearson bivariate correlation coefficient.

The influence of the variable area of study for admission to higher education, in the dimensions under study, was 
calculated with analysis of variance (ANOVA) for multiple comparisons. For the purposes of this test, the distribution of the respondents' area of study for admission to higher education was changed, since this independent variable did not meet the normality criteria. Thus, taking into account the reduced percentage of students coming from the areas of socio-economics, arts and vocational training, we decided to merge these into a single variable designated as "Other". Therefore, the revised distribution of the subjects across the different areas was as follows: science and technology (45.7\%), languages and humanities (37.2\%); other (17.1\%).

All statistical procedures were carried out with the data analysis software "Statistical Package for Social Sciences" (SPSS), version 24. The statistical significance level was set at 0.05 .

\section{Results}

\subsection{Knowledge}

Table 3 shows, in percentage form, the distribution of students' responses to the 11 items pertaining to the knowledge dimension. In order to clarify the results, the responses are each associated with Likert scale points corresponding either to a low level of agreement $(\mathrm{sd}+\mathrm{d})$, or to a high level of agreement with the content of the respective item (sa+a) while indecisive responses (nand) are shown in a column of their own. The table also displays the number of respondents $(\mathrm{N})$ for each item.

Table 3. Knowledge regarding sustainable development. Agreement and indecision with regard to content of items expressed in percentage

\begin{tabular}{|c|c|c|c|c|}
\hline Itens & $\mathbf{s d}+\mathbf{d}$ & $\mathbf{s a}+\mathbf{a}$ & nand & $\mathrm{N}$ \\
\hline $\begin{array}{l}\text { K1. Helping people out of poverty is an essential condition for Portugal to become more } \\
\text { sustainable. }\end{array}$ & 3 & 87.5 & 9.5 & 168 \\
\hline K3. Sustainable development emphasises respect for human rights. & 4.2 & 80.2 & 15.6 & 167 \\
\hline K4. Ensuring a long and healthy life for all contributes to sustainable development. & 0.6 & 89.9 & 9.5 & 168 \\
\hline K5. Building appropriate infrastructures contributes to sustainable development. & 0.6 & 83.3 & 16.1 & 168 \\
\hline K6. Sustainable development requires quality education for all. & 3 & 94 & 3 & 168 \\
\hline K7. Sustainable development emphasises gender equality. & 11.3 & 49.4 & 39.3 & 168 \\
\hline K8. Sustainable development entails a reflection on the meaning of quality of life. & 1.8 & 94.6 & 3.6 & 168 \\
\hline K12. Food safety is one aim of sustainable development. & 1.2 & 71.4 & 27.4 & 168 \\
\hline $\begin{array}{l}\text { K13. Estimating the monetary value of the service our ecosystems provide (such as: } \\
\text { neutralising air pollutants) is important for sustainable development. }\end{array}$ & 0.6 & 87.5 & 11.9 & 168 \\
\hline K14. Sustainable development emphasises international cooperation & 1.2 & 86.9 & 11.9 & 168 \\
\hline K15. Poverty alleviation is an important topic in education for sustainable development. & 1.8 & 78.5 & 19.7 & 168 \\
\hline
\end{tabular}

An examination of the table shows that in only one case did a respondent not respond to one of the items (K3). It also reveals that the majority of items have an agreement level of over $80 \%$, which is consistent with the mean scale value of $45.4 \pm 5.0$ (maximum 55). The item K8, "sustainable development entails a reflection on the meaning of quality of life", which lies at the heart of the SD concept itself, in the sense that it relates to human well-being (present and future generations) with environmental sustainability, attained the higher agreement level (94,6\%), whereas the item K7, "sustainable development emphasises gender equality", attained the lowest agreement level (49.4\%) and the highest percentage of undecided responses (39.3\%), suggesting uncertainty about their positioning within this subject.

\subsection{Attitudes}

Table 4 summarizes, in percentage form, the distribution of respondents' responses to the 10 items constituting the attitude's scale. Results are presented by following the same procedure used in the previous table. 
Table 4. Attitudes toward sustainable development. Agreement and indecision with regard to content of items expressed in percentage

\begin{tabular}{|c|c|c|c|c|}
\hline Itens & sd + d & $\mathbf{s a}+\mathbf{a}$ & nand & $\mathrm{N}$ \\
\hline $\begin{array}{l}\text { A1. Every girl or boy should receive education that teaches the knowledge, perspectives, } \\
\text { values, issues and skills for sustainable living in a community. }\end{array}$ & 0.0 & 98.8 & 1.2 & 168 \\
\hline $\begin{array}{l}\text { A2. The present generation should ensure that the next generation inherits a community at least } \\
\text { as healthy, diverse and productive as it is today. }\end{array}$ & 0.6 & 94.1 & 5.3 & 168 \\
\hline $\begin{array}{l}\text { A4. Overuse of our natural resources is a serious threat for the health and welfare of future } \\
\text { generations. }\end{array}$ & 6.6 & 90.4 & 3 & 168 \\
\hline A5. We need stricter laws and regulations to protect the environment. & 0.6 & 97 & 2.4 & 168 \\
\hline $\begin{array}{l}\text { A7. Sustainable development will not be possible until wealthier nations stop exploiting the } \\
\text { labour and natural resources of poorer countries. }\end{array}$ & 1.8 & 86.9 & 11.3 & 168 \\
\hline $\begin{array}{l}\text { A9. The teaching of sustainability principles should be integrated into the curriculum in all } \\
\text { disciplines and at all levels of schooling. }\end{array}$ & 1.8 & 89.9 & 8.3 & 168 \\
\hline A10. Governments should encourage greater use of fuel-efficient vehicles. & 0.0 & 91.1 & 8.9 & 168 \\
\hline $\begin{array}{l}\text { A11. Adopting sustainable development as a national priority is key to maintaining Portugal's } \\
\text { status as one of the most liveable countries in the world. }\end{array}$ & 1.2 & 90.5 & 8.3 & 168 \\
\hline $\begin{array}{l}\text { A12. Citizenship education is an important component of education for sustainable } \\
\text { development }\end{array}$ & 0.6 & 95.8 & 3.6 & 168 \\
\hline $\begin{array}{l}\text { A13. Taxes on polluters should be increased to pay for damage to communities and the } \\
\text { environment. }\end{array}$ & 3.6 & 77.8 & 18.6 & 167 \\
\hline
\end{tabular}

The table shows that in only one case did a respondent not respond to one of the items (A13). Overall, respondents' attitude towards SD is very favourable, and most items produced responses with an agreement level of over $90 \%$. The mean scale value of $43.7 \pm 4.2$ (maximum 50) confirms the respondents' very favourable evaluation of attitudes towards SD.

Too items meriting special attention, the item A1 - every girl or boy should receive education that teaches the knowledge, perspectives, values, issues and skills for sustainable living in a community - which obtained an agreement level of $98.8 \%$ and only $2.1 \%$ of undecided responses. This level of approval for an item whose content emphasizes the importance of education for sustainable living is in line with the knowledge dimension (Table 1) where respondents also expressed high recognition of the role of education in SD. However, the item A13, which appeals to a more contentious position on sustainable development, received the lowest, yet also a considerable, level of agreement $(77,8 \%)$.

\subsection{Behaviours}

In order to facilitate analysis of the results obtained, it was decided to group, on the one hand, data related to less favourable responses to SD according to the scale points never $(\mathbf{n})$ and rarely (r), while, on the other hand, grouping the more favourable responses corresponding to the remaining scale points, regularly (re), often (o), and very often (vo) (Table 5). The table also shows the number of respondents $(\mathrm{N})$ for each item.

As indicated in Table 5, the $\mathrm{N}$ value shows slight fluctuations with only five items answered by all respondents with a maximum of three responses lacking in item B 6. This lack of responses may be attributed to the fact that the response format does not include a neutral category, an option that was intended to "force" respondents' choice. In any case, the format chosen has no influence on the distribution of responses at the negative and positive poles of the scale but may cause some respondents to avoid responding (Saris \& Gallhofer, 2007). 
Table 5. Behaviours relative to sustainable development. Levels of commitments expressed in percentage

\begin{tabular}{|c|c|c|c|}
\hline Itens & $\mathbf{n}+\mathbf{r}$ & re $+\mathbf{o}+$ vo & $\mathrm{N}$ \\
\hline B 1. I walk or bike to places instead of going by car. & 32.2 & 67.2 & 167 \\
\hline B 2. I have taken a course in which sustainable development was discussed. & 54.8 & 45.2 & 168 \\
\hline B 3. I talk to others about how to help people living in poverty. & 18.5 & 80.1 & 167 \\
\hline B 4 . I have been thinking about what it means to live in a sustainable manner. & 23.8 & 76.2 & 168 \\
\hline $\begin{array}{l}\text { B. } 5 \text {. The household tasks in my home are equally shared among family members } \\
\text { regardless of gender. }\end{array}$ & 25 & 73.8 & 166 \\
\hline B. 6. I often look for signs of ecosystem deterioration. & 38.1 & 60.1 & 165 \\
\hline B. 7. I volunteer to work with local charities. & 40.5 & 58.9 & 167 \\
\hline B. 8 I have already participated in activities related to environmental sustainability. & 52.9 & 47.1 & 168 \\
\hline $\begin{array}{l}\text { B } 9 \text {. I try to avoid purchasing goods from companies with poor track records on corporate } \\
\text { social responsibility. }\end{array}$ & 42.2 & 57.2 & 167 \\
\hline B 10. I usually look at problems from different angles. & 10.7 & 88.7 & 167 \\
\hline $\begin{array}{l}\text { B } 11 \text {. I have already looked up information about the environment or sustainability of } \\
\text { the university on the respective website. }\end{array}$ & 53 & 47 & 168 \\
\hline $\begin{array}{l}\text { B 12. I have already looked up information about the new sustainable development goals } \\
\text { of the United Nations. }\end{array}$ & 63.6 & 36.4 & 168 \\
\hline
\end{tabular}

The students' responses show that overall there is a relative balance between the most and least committed responses to $\mathrm{SD}$ as is indicated by the mean scale value of $35.1 \pm 7.9$ (maximum 60).

The responses obtained by items B10, B 3, B 4 and B 5 showed the highest levels of commitment to SD. The behaviours underlying the statements contained in these items convoke critical thinking (B10); responsibility regarding poverty (B 3); human needs and natural resources (B 4) and gender equality (B 5).

As regards the responses showing least support, the percentage responses to four items show a lower level of commitment to SD: B12; B 2; B 8 and B11. The behaviours underlying the statements contained in these items are more or less directly related to participation in $\mathrm{SD}$ activities or to an active search for training or information linked to SD.

A Pearson correlation analysis was performed with the following results: The knowledge and attitudes dimensions have the higher correlation value $(r=0.589, \mathrm{p}=0,000)$; the knowledge and behaviours dimensions have a relatively lower correlation $(r=0.251, \mathrm{p}=0,001)$ and the lowest correlation value was obtained by the attitudes and behaviours' dimensions $(r=0.154, \mathrm{p}=0,053)$. These results also show that correlations between knowledge and attitudes and between knowledge and behaviours are statistically significant at the 0.01 level.

\subsection{Area of Study for Admission to Higher Education}

Influence of the variable area of study for admission to higher education, sub-groups Science and Technology (75), Languages and Humanities (61) and Other (28), in the dimensions under analysis was determined using an analysis of variance (Table 7).

Table 7. ANOVA Knowledge Attitudes and Behaviours

\begin{tabular}{|c|c|c|c|c|c|c|}
\hline & Source of variance & Sum of Squares & $\mathrm{df}$ & Mean Square & $\mathrm{F}$ & $\mathrm{P}^{*}$ \\
\hline \multirow{3}{*}{ knowledge } & Between groups & 92.934 & 2 & 46.467 & & \\
\hline & Within groups & 4141.937 & 160 & 25.887 & 1.795 & 0.169 \\
\hline & total & 4234.871 & 162 & & & \\
\hline \multirow{3}{*}{ attitudes } & Between groups & 1,940 & 2 & 0,970 & & \\
\hline & Within groups & 2922.713 & 161 & 18.153 & 0.053 & 0.948 \\
\hline & total & 2924.652 & 163 & & & \\
\hline \multirow{3}{*}{ behaviours } & Between groups & 71.555 & 2 & 35.778 & & \\
\hline & Within groups & 9623.438 & 153 & 62.898 & 0.569 & 0.567 \\
\hline & total & 9694.994 & 155 & & & \\
\hline
\end{tabular}

Note. * Statistically significant differences below 0.05

The analysis shows that there are no statistically significant differences between the subgroups of students concerning knowledge $(\mathrm{p}=0.169)$; attitudes $(\mathrm{p}=0.948)$; and behaviours $(\mathrm{p}=0.567)$, leading to the conclusion 
that the independent variable is not very influential.

\section{Discussion}

The instrument used in the study has shown to have a three-dimensional structure allowing measurement of knowledge, attitudes and behaviours related to various SD themes. With reference to the topics included in the items of the questionnaire, it is clear that the subject group studied have knowledge and attitudes that are largely favourable to the majority of the selected themes relevant to SD. As far as behaviours are concerned, the group were not overall as favourable to SD as with the other two dimensions, further, it was found that the stronger correlation was established between knowledge and attitudes and the weaker one between attitudes and behaviours. With regard to student's academic background, the area of study for admission to higher education have shown not to be influential in the responses given by this group of students.

The high level of agreement obtained on the knowledge dimension indicates that students are aware of the relevance to SD of such themes as sustainable living, education, health, ecosystems, poverty; international cooperation, infrastructure; human rights and food security. However, only half of the respondents acknowledged the importance of gender equality for sustainable development, which is in line with Michalos et al. (2011), who obtained a similar result in their study. The relative lack of support regarding the importance to this issue could result from the fact that respondents perceived that equal rights and opportunities between men and women are already a reality in key areas of their social life and/or because they do not understand their relevance to SD. In this regard, more investigation is therefore needed about people's actual conceptions about this SD theme. As regards the attitudes dimension, the high level of agreement with the items of the scale and the low levels of uncertainty showed a strongly positive attitude towards SD. Positive attitudes towards SD among university students were also reported in studies such us Biassuti (2017), Gündüz (2017), Keles (2017) and Al-Naqbi and Alshannag (2018). As we said before, the behaviours' dimension got a more modest score. The contrast with the high scores obtained in the knowledge and attitudes dimensions seems to indicate that there is a gap between the support that those dimensions merited and the adoption of certain pro-DS behaviours. This seems to bring evidence to the idea that, in addition of knowledge and attitudes, other factors contribute to pro-SD behaviours (Too \& Bajracharya, 2015). In the field of EE, the relationships that exist between knowledge-attitudes-behaviours have been intensively studied and it is now generally accepted that the adoption of pro-environmental behaviours is a complex issue involving multiple variables, both external and internal (Kollmuss \& Agyeman, 2002; Heimlich, Mony \& Yocco, 2013). Since the concept of SD is even more complex than that of environment, it is legitimate to assume that the factors that determine pro-SD behaviours are equally complex and multiple.

The results of the present research suggest that certain obstacles affect adoption of some pro-SD behaviours underlying the items under analysis. This study cannot identify the causes of these obstacles but it can be argued that at least two types of factors are involved, some being of a personal nature, such as lack of available time or lack of motivation, while others may be related to social and institutional factors, such as the lack of supply or dissemination of activities specifically directed to SD. One of the educational implications regards the nature of institutional initiatives aiming to promote and increase the visibility of training and education in SD, such as the dynamization of extracurricular activities related to sustainability on campus, which could play a positive role in overcoming these barriers and help students to get more involved. In a more sustainable future perspective, it is fundamental that higher education contributes to amplify information and learning opportunities in this field, both in formal and informal contexts. The results have also shown that the participating subjects have shown to be sensitized and committed to knowledge pertaining to the area of SD. A further educational implication, therefore, concerns the contribution of the study to a better understanding of prospective teachers' approaches to $\mathrm{SD}$, which, in turn, contributes to a better framing of professional development in this field.

Leaving aside the above-mentioned limitation inherent to the process of questionnaire validation, it is important to stress that a major limitation of this study lies in the small size and cultural homogeneity of the group that was studied, making the results obtained not generalizable to other situations.

\section{Acknowledgments}

This work was funded by CIEC (Research Centre on Child Studies at the University of Minho) with POCI-01-0145-FEDER-007562 reference

\section{References}

Al-Naqbi, A., \& Alshannag, Q. (2018). The status of education for sustainable development and sustainability knowledge, attitudes, and behaviors of UAE university students. International Journal of Sustainability in 
Higher Education, 19(3), 566-588. https://doi 10.1108/IJSHE-06-2017-0091

Aleixo, A., Azeiteiro, U., \& Leal, S. (2018). The implementation of sustainability practices in portuguese higher education institutions. International Journal of Sustainability in Higher Education, 19(1), 146-178, https://doi.org/10.1108/IJSHE-02-2017-0016

Ambusaidi, A., \& Washahi, M. (2016). Prospective teachers' perceptions about the concept of sustainable development and related issues in Oman. Journal of Education for Sustainable Development, 10(1), 3-19. https://doi.org/10.1177/0973408215625528

Azeiteiro, U., Nicolau, P., Caetano, F., \& Caeiro, S. (2015). Education for sustainable development through e-learning in higher education: Experiences form Portugal, Journal of Cleaner Production, 106, 308-319, http://dx.doi.org/10.1016/j.jclepro.2014.11.056

Biasutti, M., \& Frate, S. (2017). A validity and reliability study of the attitudes toward sustainable development scale. Environmental Education Research, 23(2), 214-230. http://dx.doi.org/10.1080/13504622.2016.1146660.

Borg, C., Gericke, N., Höglund, H-O., \& Bergman, E. (2012). The barriers encountered by teachers implementing education for sustainable development: Discipline bound differences and teaching traditions. Research in Science \& Technological Education, 30(2), 185-207.

http://dx.doi.org/10.1080/02635143.2012.699891

Borg, C., Gericke, N., Höglund, H-O., \& Bergman, E. (2014). Subject-and experience-bound differences in teachers' conceptual understanding of sustainable development. Environmental Education Research, 20(4), 526-551. http://dx.doi.org/10.1080/13504622.2013.833584

Borges, F., \& Benayas, J. (2019). Research in EE and EDS in Portuguese public universities. International Journal of Sustainability in Higher Education, 20(1), 57-74. https://doi.org/10.1108/IJSHE-05-2018-0091

Burmeister, M., \& Eilks, I. (2013). An understanding of sustainability and education for sustainable development among German student teachers and trainee teachers of chemistry. Science Education International, 24(2), 267-194.

Cotton, D., Warren, M., Maiboroda, O., \& Bailey, I. (2007). Sustainable development, higher education and pedagogy: A study of lecturers' beliefs and attitudes. Environmental Education Research, 13(5), 579-597. https://doi.org/10.1080/13504620701659061

DeVellis, R. (2012). Scale development - Theory and applications. Washington DC: Sage Publications.

Eagly, A., \& Chaiken, S. (2005). Attitude research in the $21^{\mathrm{ST}}$ century: The current state of knowledge. In Albarracin, D.; Johnson, B. e Zanna, M. (Eds.), The Handbook of Attitudes (pp. 743-767), New Jersey: Lawrence Erlbaum Associates.

Gündüz, S. (2017). A Research about attitudes and behaviors of university students with having different cultures towards the environment through sustainable development. EURASIA Journal of Mathematics Science and Technology Education, 13(6), 1881-1892. https://doi.org/10.12973/eurasia.2017.01206a

Heimlich, J., Mony, P., \& Yocco, V. (2013). Belief to behavior. In Stevenson, R.; Brody, M.; Dillon, J. and Wals, A. (Eds.), International handbook of research on environmental education (pp. 262-274). New York: Routledge Publishers.

Keles, Ö. (2017). Investigation of pre-service science teachers' attitudes towards sustainable environmental education. Higher Education Studies, 3(7), 171-180. http://doi.org/10.5539/hes.v7n3p171.

Kollmuss, A., \& Agyeman, J. (2002). Mind the gap: Why do people act environmentally and what are the barriers to pro-environmental behavior? Environmental Education Research, 8(3), 239-260.

Michalos, A., Creech, H., McDonald, C., \& Kahlke, P. (2011). Knowledge, attitudes and behaviours concerning education for sustainable development: Two exploratory studies. Social Indicators Research, 100, 391-413. https://doi.org/10.1007/s11205-010-9620-9.

Michalos, A., Creech, H., Swayze, N., Kahlke, P., Buckler, C., \& Rempel, K. (2012). Measuring knowledge, attitudes and behaviours concerning sustainable development among tenth grade students in Manitoba. Social Indicators Research, 106, 213-238. https://doi.org/10.1007/s11205-011-9809-6.

Olsson, D., Gerickea, N., \& Chang, R. S.-N. (2016). The effect of implementation of education for sustainable development in swedish compulsory schools - Assessing pupils' sustainability consciousness. 
Environmental Education Research, 22(2), 176-202. http://dx.doi.org/10.1080/13504622.2015.1005057

Robottom, I. (2013). Changing Discouse in EE/EDS - A role for professional sel-development. In Stevenson, R.; Brody, M.; Dillon, J. and Wals, A. (Eds.), International handbook of research on environmental education (pp. 156-162). New York: Routledge Publishers.

Saris, W., \& Gallhofer, I. (2007). Design, evaluation, and analysis of questionnaires for survey research. New Jersey: Published by Jonh Wiley \& Sons.

Scoullos, M., \& Malotidi, V. (2004). Handbook on methods in environmental education and education for sustainable development. Athenes: Mio-ECSDE.

Singer-Brodowski, M. (2017). Pedagogical content knowledge of sustainability - a missing piece in the puzzle of professional development of educators in higher education for sustainable development. International Journal of Sustainability in Higher Education, 18(6), 841-856.

Stevenson, R. (2013). Researching tensions and pretensions in environmental/sustainability education policies: From critical to civically engaged policy scholarship. In Stevenson, R.; Brody, M.; Dillon, J. and Wals, A. (Eds.), International handbook of research on environmental education (pp. 147-155). New York: Routledge Publishers.

Tilbury, D. (1995). Environmental education for sustainability: Defining the new focus of environmental education in the 1990s. Environmental Education Research, 1(2), 195-212.

Too, L., \& Bajracharya, B. (2015). Sustainable campus: Engaging the community in sustainability. International Journal of Sustainability in Higher Education, 16(1), 57-71. https://doi.org/10.1108/IJSHE-07-2013-0080

Torres, R., Vieira, R., Rodrigues, A., Sá, P., \& Moreira, G. (2017). Education for sustainable development: An exploratory study in a portuguese university. International Journal of Sustainability in Higher Education, 18(6), 956-970. https://doi.org/10.1108/IJSHE-05-2016-0082.

Ull, M., Piñero, A., Martínez-Agut, M. P., \& Minguet, P. (2014). Preconcepciones y actitudes del profesorado de magisterio ante la incorporación en su docencia de competencias para la sostenibilidad [Preconcepcions and attitudes of teachers of teaching school about incorporated sustainability competences in their teaching]. Enseñanza de las Ciencias, 32(2), 91-112. http://dx.doi.org/10.5565/rev/ensciencias.904

UNCED (1993). Agenda 21: Programme of action for sustainable development. Rio de Janeiro: United Nations Conference on Environmental Development.

UNESCO (2003). United nations decade of education for sustainable development (2005-2014): Framework for the international implementation scheme. Paris: UNESCO.

UNESCO Education Sector (2006). Framework for the undesd international implementation scheme. Paris: UNESCO.

\section{Copyrights}

Copyright for this article is retained by the author(s), with first publication rights granted to the journal.

This is an open-access article distributed under the terms and conditions of the Creative Commons Attribution license (http://creativecommons.org/licenses/by/4.0/). 